\title{
Utilização de Adubação Orgânica com Dejetos de Suínos e Contaminação de Água e de Solo por Coliformes
}

\section{Utilization of organic fertilization with pig slurry and contamination of watet and soils of coliform}

\author{
Eliana Aparecida Cadoná1, Eduardo Lorensi de Souza², Divanilde Guerra² e \\ Robson Evaldo Gehlen Bohrer ${ }^{3}$. \\ ${ }^{1}$ Especialista, Programa de Pós-Graduação em Agroecossistemas, Universidade Federal de Santa Catarina, Florianópolis/SC, \\ Brasil \\ elianacadona@yahoo.com.br \\ ${ }^{2}$ Doutor, Regional IV, Universidade Estadual do Rio Grande do Sul, Três Passos/RS, Brasil \\ elorensi@yahoo.com.br;divanildeguerra@yahoo.com.br \\ ${ }^{3}$ Mestre, Regional IV, Universidade Estadual do Rio Grande do Sul, Três Passos/RS, Brasil \\ gehlenbohrer@gmail.com
}

\begin{abstract}
Resumo
A aplicação de dejetos líquidos de suínos (DLS) é uma técnica utilizada como fonte de nutrientes em áreas agricultáveis, porém, sua constituição microbiológica apresenta contaminantes de solo e água. O objetivo do presente trabalho foi verificar a existência de contaminação por coliformes nas águas em uma propriedade adjacente ao Lajeado Erval Novo. A metodologia adotada consistiu em coletas de água no Lajeado e de solo na propriedade adjacente, para avaliação através do Número Mais Provável (NMP) para coliformes totais (CT) e para termotolerantes (CTermo) e para microorganismos aeróbios heterotróficos (MAH), usando o Standard Methods, no período de março a outubro de 2014. Verificou-se que o NMP de CT nas amostras de água variaram entre 240 e

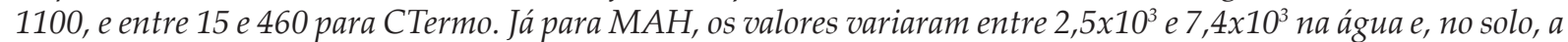
variação para CT foi entre 2300 e $79 \times 10^{2}$, e CTermo o NMP variou entre 22 e $43 \times 10^{2}$. Após as coletas, confirmou-se a contaminação por bactérias do grupo dos coliformes no solo e na água, podendo estar relacionado com a aplicação de DLS em áreas agricultáveis, com o carreamento desses DLS para o Lajeado pelas águas das chuvas.
\end{abstract}

Palavras-chave: Agricultura; Qualidade da água; Qualidade do solo.

\begin{abstract}
The application of pig slurry (DLS) is a technique used as a source of nutrients in agricultural areas, however, microbiological constitution presents soil contaminants and water. The aim of this study was to verify the existence of contamination by coliforms in the water in an adjacent property to Lajeado Erval New. The methodology consisted of water collected in Lajeado and soil on the property adjacent to evaluation by the Most Probable Number (MPN) for total coliforms (TC) and thermophilic (CTermo) and heterotrophic aerobic microorganisms (MAH), using the Standard Methods for the period from March to October 2014. it was found that the CT of NMP in water samples varied between 240 and 1100, and between 15 and 460 for CTermo. As for TSP, values ranged from $2,5 \times 10^{3} 7,4 \times 10^{3}$ and water and in the soil, the variation was from 2300 to $C T$ and $79 \times 10^{2}$ and CTermo NMP ranged from 22 to $43 \times 102$. After the collection, it was confirmed contamination by bacteria from the group of coliforms in soil and water and can be related to the application of DLS in agricultural areas, with the entrainment of these DLS for Lajeado by rainwater.
\end{abstract}

Keywords: Agriculture; Water quality; Soil quality. 


\section{Introdução}

A água é um recurso não renovável, por isso a sua grande importância para os seres vivos. Alguns estudos demonstram que a água recobre aproximadamente $80 \%$ da superfície do planeta Terra, sendo que deste, 97\% estão nos oceanos (RESENDE; MERTEN \& MINELLA, 2002). Desse total, estima-se ainda que somente 3\% é água doce, e que apenas uma pequena parte disso está disponível para o consumo humano ou animal de forma imediata (RESENDE, 2002). Essa questão torna-se ainda mais alarmante e preocupante quando se analisa que a pequena porção de água doce no planeta está sob constante poluição, o que causa a degradação desse recurso principalmente em decorrência da ausência de políticas públicas de preservação dos recursos hídricos (MERTEN \& MINELLA, 2002).

O Brasil possui grandes rios e bacias hidrográficas, no entanto, essa água não está distribuída de forma homogênea entre a população, devido à grande extensão territorial do país e pela má distribuição dessa população neste vasto território. O Brasil possui também uma grande área de reserva subterrânea, conhecida como Aquífero Guarani que apresenta uma área de aproximadamente $1.196 .500 \mathrm{~km} 2$, situado em áreas brasileiras, argentinas, uruguaias e paraguaias (RIBEIRO, 2008). Essa grande extensão de áreas com disponibilidade de água faz a gestão de esse recurso ser desafiadora, pois ao analisar a extensão territorial brasileira e seu desenvolvimento econômico, sabe-se da necessidade de água para esse, e, consequentemente, da carga poluidora que os corpos hídricos poderão receber nesse processo de modernização (MERTEN \& MINELLA, 2002). Essa carga poluidora em corpos hídricos superficiais e subterrâneos poderá comprometer a qualidade da água para fins de abastecimento doméstico, decorrente de poluição causada por diferentes fontes, tais como efluentes domésticos, efluentes industriais e deflúvio superficial urbano e agrícola (MERTEN \& MINELLA, 2002). Tal é a carga poluidora que os mananciais hídricos recebem devido às atividades exercidas no Brasil, que essa carga poluidora da água pode ser dividida por regiões conforme a atividade econômica predominante, porém, independente da região, pode-se atribuir o despejo de esgotos domésticos e industriais em corpos hídricos como uma boa parte da parcela de contaminação. Na região Sul do Brasil, além dos diversos efluentes que podem causar contaminação das águas e do solo, os sistemas de confinamento e a agricultura são potenciais poluidores e grandes consumidores de água. Algumas atividades agrícolas necessitam grandes quantidades de água, além de outros insumos necessários para o desenvolvimento e manutenção das culturas, como os fertilizantes e os dejetos de animais, ambos utilizados para o fornecimento de nutrientes às plantas cultivadas (REICHARDT \& TIMM, 2010).

No Brasil, semelhante ao que ocorre em outros países, os dejetos de animais são utilizados como adubação orgânica para o fornecimento de nutrientes às culturas, sendo um processo que utiliza os resíduos de origem animal (esterco ou urina) geralmente provenientes de locais de confinamento de aviários (aves) e chiqueirões (suínos), também podendo ser utilizado a partir de restos vegetais (PAULUS apud SILVA, 2008). Essa forma de adubação tem como principal objetivo aumentar a fertilidade e a disponibilidade de nutrientes para as culturas agrícolas, como o nitrogênio $(\mathrm{N})$, fósforo $(\mathrm{P})$, potássio $(\mathrm{K})$, cálcio $(\mathrm{Ca})$ e o magnésio $(\mathrm{Mg})$ no solo, auxiliando também na melhora da microbiota do solo. A grande produção de resíduos de origem animal, como por exemplo, estercos, dejetos, entre outros, constitui-se num problema ambiental, principalmente, em sistemas de confinamentos. Estes resíduos, quando depositados em locais inadequados podem resultar na contaminação dos solos e das águas (ECKHARDT, 2011; MORALES, 2011).

Dentre os diversos tipos de adubação orgânica que podem ser utilizadas para o fornecimento de nutrientes às culturas, um dos adubos orgânicos que são mais utilizados são os dejetos líquidos de suínos (DLS), em especial em regiões grandes produtoras de suínos em sistema de confinamento, como é o caso da região Noroeste do estado do Rio Grande do Sul (RS). O sistema de confinamento de suínos gera o consumo elevado de água para o estabelecimento rural e também os dejetos na forma líquido, com elevado potencial poluidor (DONEDA, 2014). Tendo em vista a utilização dos DLS nas propriedades rurais como fonte de nutrientes para as culturas agrícolas sem os devidos cuidados, também é possível que ocorram outros tipos de contaminação, como por exemplo, por bactérias dos grupos coliformes, que são eubactérias gram-negativas ou bacilos facultativos, que podem crescer tanto em ambientes aeróbios quanto anaeróbios, bactérias essas pertencentes à família das Enterobacteriaceae, que causam diversos problemas no sistema gastrointestinal e urinário em humanos (PELCZAR et al., 1997). Por essa questão, existe a Resolução nº 357/2005 do Conselho Nacional do Meio Ambiente (CONAMA), que define que esses coliformes devem estar ausentes em $100 \mathrm{ml}$ de água em $80 \%$ das amostras em um período de um ano.

Sendo assim, os mananciais hídricos e fontes de abastecimentos próximos de áreas agrícolas e, que recebem adubação orgânica através do uso dos DLS, devem ser bem manejadas e monitoradas, no intuito de não haver riscos de contaminação por coliformes advindos dos DLS, bem como pelo manejo de esterqueiras ou lagoas de depósito dos dejetos (MARQUES, 2005), para que a qualidade das águas não seja alterada, principalmente no que diz respeito à contaminação por coliformes, causadores de diversos problemas, conforme a resolução vigente. Nesse contexto, o objetivo desse trabalho foi verificar a presença de coliformes totais e termotolerantes no solo e na água e, de microorganismos aeróbios heterotróficos na água, em decorrência da utilização da adubação orgânica com DLS em áreas costeiras ao 
Lajeado Erval Novo no Município de Três Passos/RS.

\section{METODOLOGIA}

\section{Descrição do local de estudo}

O estudo foi realizado de março à outubro de 2014 em uma propriedade rural no município de Três Passos, região Noroeste do RS. Hidrograficamente esta região está na bacia dos rios Turvo-Santa Rosa-Santo Cristo, a qual pertence a bacia do Rio Uruguai. O clima da região é Subtropical Úmido (Cfa) conforme a classificação de Köppen-Geiger, com precipitação média anual acima dos $1.000 \mathrm{~mm}$.

Para a escolha da propriedade onde foram realizadas as coletas de água e solo, buscou-se dados na Secretaria Municipal de Meio Ambiente (SMMA) do município de Três Passos, identificando a presença de criatórios de suínos em até $500 \mathrm{~m}$ de distância do Lajeado Erval Novo. Dentro deste padrão, somente uma propriedade rural foi encontrada dentro dos limites territoriais do município. A propriedade está aproximadamente $5 \mathrm{~km}$ distantes do centro do município. Sendo que o Lajeado Erval Novo passa aos fundos da mesma e existe a criação em fase de terminação de aproximadamente 500 suínos, onde os seus dejetos são utilizados como adubo orgânico em parte da propriedade.

As áreas da propriedade que são utilizadas para cultivos comerciais de inverno e verão recebem aproximadamente 1,4 m3 ha-1 ano-1 em uma única aplicação, no mês de julho, com auxílio de um caminhão tanque, próprio para a distribuição dos DLS na área. A área de estudo apresenta declividade média de $8,2 \%$ em direção ao Lajeado, contendo locais com potencial de arraste dos DLS pelas chuvas, para dentro do Lajeado. Durante o período desse estudo, também foram registradas as precipitações ocorridas na região.

\section{Coletas de água e de solo}

Os pontos de coleta de água do Lajeado Erval Novo foram determinados no intuito de se verificar a existência de contaminação das águas e, se eventualmente, as aplicações dos DLS podem estar contribuindo para a contaminação do manancial. Para tal, tomaram-se cinco pontos de coletas pré-definidos, sendo: um ponto antes da propriedade ("ponto 2 - 27을 $24^{\prime} 4^{\prime \prime} S$ e $53^{\circ} 58^{\prime} 36^{\prime \prime}$ O); um ponto no Lajeado nos fundos da propriedade (pontos 3 - 27을 $35^{\prime \prime}$ S e 53ำ5 '37" O) com potencial de possível escoamento superficial das chuvas de dentro da propriedade para o Lajeado; um ponto abaixo da

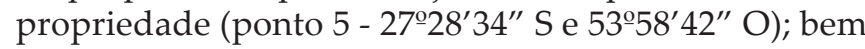
como outros dois pontos, um a montante e outro a jusante da propriedade (pontos $1-27^{\circ} 48^{\prime} 31^{\prime \prime} \mathrm{S}$ e $53^{\circ} 96^{\prime} 59^{\prime \prime} \mathrm{O}$ e

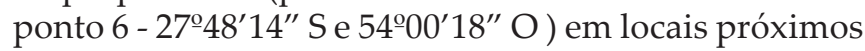
de coleta da concessionária pública de abastecimento de água do município, conforme figura 01.

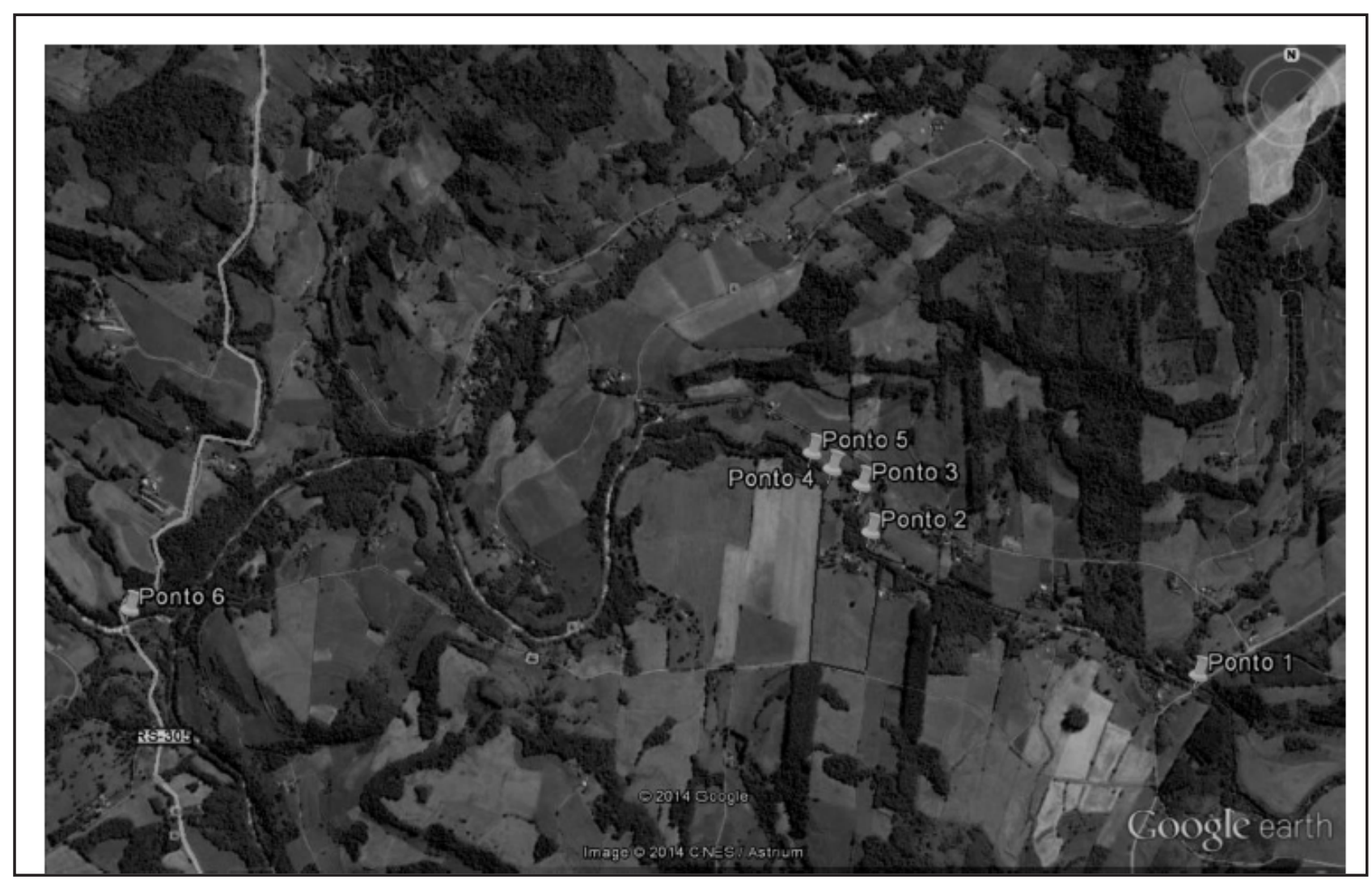

Figura 01 - pontos de coleta de água e solo. 
As coletas de água foram realizadas em 25/03, 26/05 e 16/07 de 2014, entre as 06:00 e as 07:00 horas. Em cada ponto, foram coletados $100 \mathrm{ml}$ de água com o auxílio de um recipiente previamente limpo. Após, as amostras de água eram armazenadas em frascos de coleta de $50 \mathrm{ml}$ cada e, depois, acondicionados em bolsa refrigerada, sendo estes então encaminhados ao Laboratório de Análises de Efluentes da Universidade Regional Integrada do Alto Uruguai e Missões, no município de Frederico Westphalen/RS, para análises de coliformes totais e termotolerantes (Escherichia coli), além de microorganismos aeróbios heterotróficos.

As coletas de solo foram feitas no ponto 4 ( $27^{\circ} 28^{\prime} 37^{\prime \prime}$ S e $53^{\circ} 58^{\prime} 40^{\prime \prime}$ O), visto que este ponto é um local representativo do solo da propriedade, adjacente ao Lajeado Erval Novo. O solo foi caracterizado como um Neossolo (STRECK, 2008). As coletas de solo foram realizadas nos dias 25/03, 26/05, 23/07 e 02/09 de 2014, entre as 13:00 e as 15:00 horas. As coletas de solo foram realizadas na profundidade de $0-30 \mathrm{~cm}$. As amostras de solo eram coletadas e aeradas à sombra, e após, acondicionadas em sacos plásticos de aproximadamente 500 g. Após, essas amostras foram encaminhadas ao Laboratório Centro de Pesquisa em Alimentação, para a análise do número mais provável (NMP) para coliformes totais e termotolerantes, no município de Passo Fundo.

\section{Análises de água e solo}

Para a análise laboratorial das amostras de água e de solo coletadas, o padrão estabelecido foi do NMP/100 $\mathrm{ml}$ e NMP/g, que fornece o NMP de coliformes totais, termotolerantes e microorganismos aeróbios heterotróficos. O método utilizado foi o estabelecido pelo "Standard Methods for the examination of water and wastewater", em sua 22a edição, ano de 2012, a partir do método número 9221, que segundo Leite et al. (2006) é o método tradicional, que utiliza de tubos múltiplos para a determinação do NMP de bactérias de origem fecal.

\section{Resultados e Discussão}

\section{Precipitação, coliformes totais, termotoleran-}

\section{tes e unidades formadoras de colônias na água}

Durante o período experimental, as precipitações ocorridas variaram entre 3 e $110 \mathrm{~mm}$ diários, conforme a figura 02.

No período experimental, ocorreram $1.727 \mathrm{~mm}$, sendo o mês de setembro o que teve a maior precipitação (325 mm), segundo dados da Estação Meteorológica de Santo Augusto do Instituto Nacional de Meteorologia (INMET, 2014).

Observando-se a figura 03 é possível verificar que nas amostragens de água, no ponto 1 (a montante da propriedade e próximo de um ponto de coleta da concessionária de abastecimento de água de Três Passos) os valores do Número Mais Provável (NMP) de coliformes totais foram os seguintes: 460, 240 e 460, em 25/03, 27/05 e 16/07, respectivamente. Já os resultados de NMP para os coliformes termotolerantes foram os seguintes: 43,93 e 460, em 25/03, 27/05 e 16/07 de 2014.

Os resultados de NMP encontrados para coliformes totais nas coletas de água podem estar relacionados tanto com a própria carga poluidora que o manancial recebe durante seu curso quanto com a influência das áreas agrícolas adjacentes ao Lajeado, visando que, a atividade suinícola e de produção de grãos é de essencial importância na economia regional. Outro fator que pode contribuir para a presença dos coliformes nas águas do

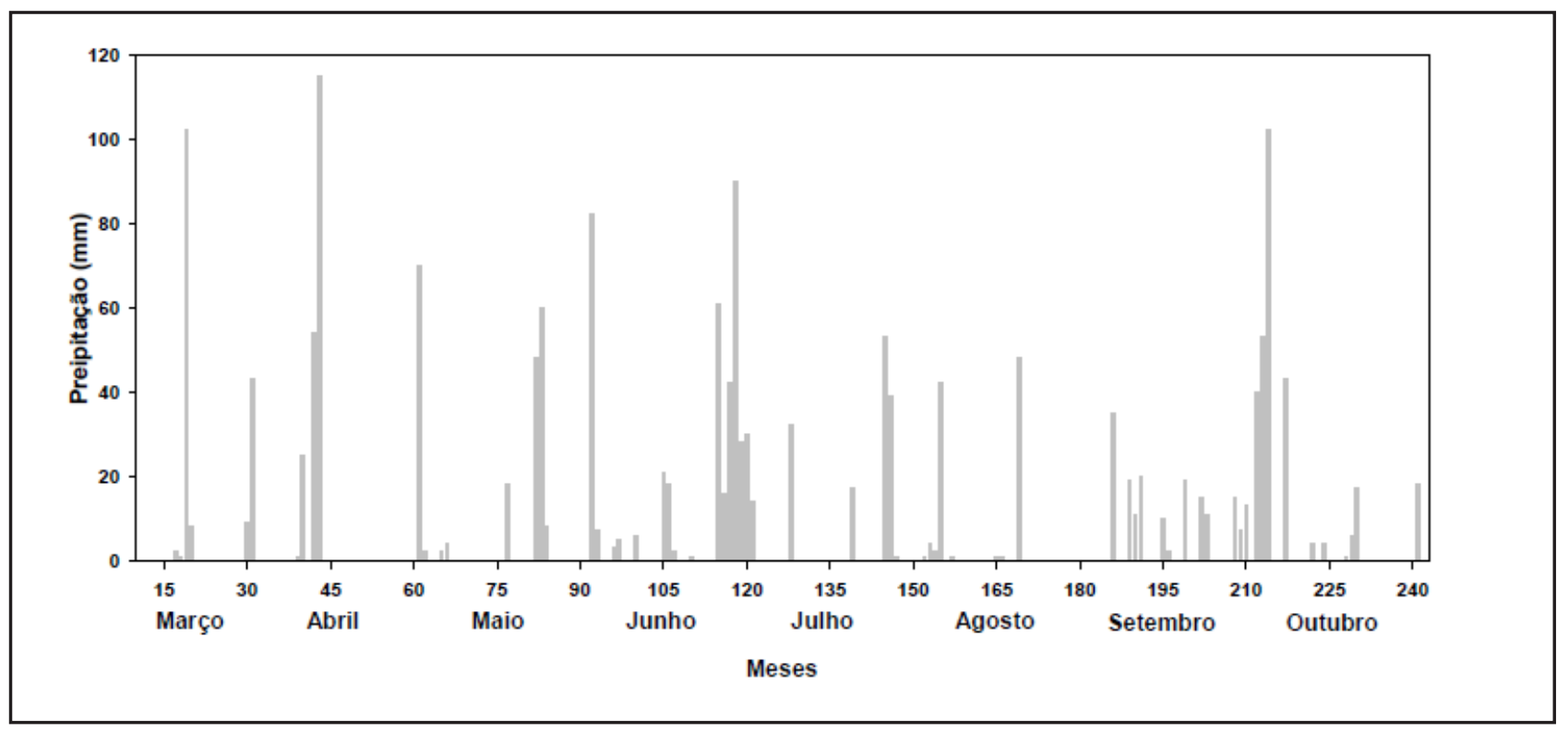

Figura 02 - Precipitações (mm) ocorridas entre os meses de março e outubro de 2014. 


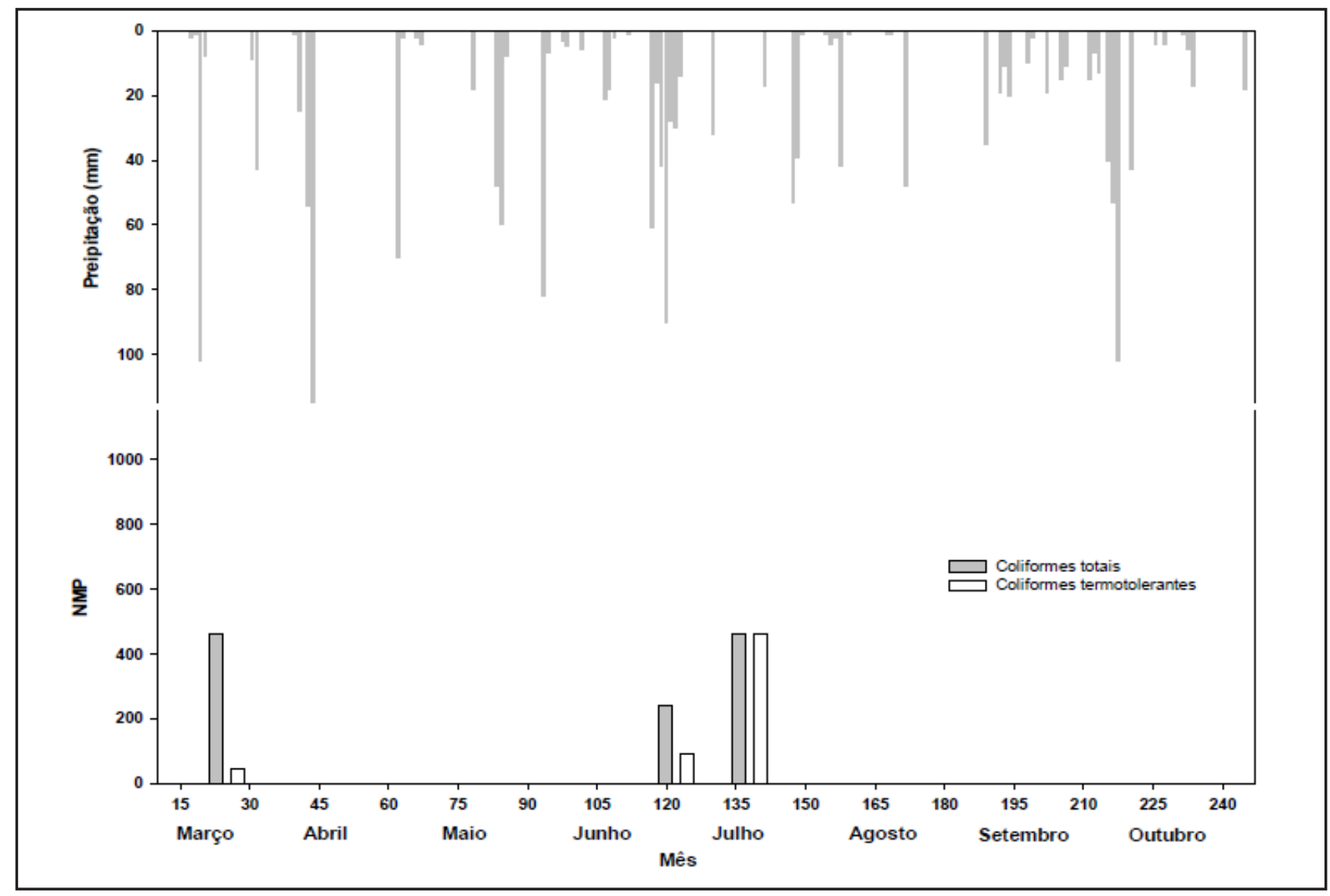

Figura 03 - Número mais provável (NMP) de coliformes totais e termotolerantes no ponto 1 de coleta de água e precipitação ocorrida entre os meses de março e outubro de 2014.

Lajeado Erval Novo é a ocorrência de chuvas em alta intensidade, que podem carregar esses microorganismos presentes nas áreas adjacentes ao Lajeado para dentro desse manancial, através do escoamento superficial das águas, carregando os microorganismos para dentro do manancial hídrico e causando a sua contaminação. Para os coliformes fecais, por exemplo, a sobrevivência e o transporte para o meio ambiente dependerão de uma série de fenômenos complexos devido às interações dos processos que regulam essa movimentação no solo (RODRIGUES et al., 2011; JACOBSEN et al., 2012), como a taxa de infiltração de água no solo propiciado o escoamento superficial (UNC et al., 2004).

As diferenças nos resultados de NMP observados entre as coletas (Figura 03) podem estar relacionados principalmente com as precipitações ocorridas, o que pode ter influenciado tanto no escoamento e carregamento de microorganismos de áreas adjacentes ao Lajeado e também na diluição dessa contaminação pelo aumento da vazão desse quando da ocorrência das precipitações. Isso pode ser observado na figura 03, pois o menor valor de NMP para coliformes totais ocorreu quando da incidência das precipitações mais intensas de até $90 \mathrm{~mm}$. Analisando os valores de coliformes totais e termotolerantes, Cavalcante (2014) observou que esses podem variar na água em poucos dias, dependendo de condições ambientais (clima, mata ciliar, uso do solo, temperatura, disponibilidade de nutrientes) e nas proximidades dos pontos de coleta. Além disso, ocorrem diferenças na concentração de coliformes em épocas de chuvas e estiagem (AMARAL et al., 2003; VASCONCELLOS et al., 2006).

No ponto 6 de coleta (Figura 04) de água (a jusante da propriedade e próximo de outro ponto de coleta de água da concessionária de abastecimento de Três Passos) observou-se valores de NMP acima dos padrões estabelecidos pela Resolução nº 357/2005 do CONAMA para o consumo humano, sendo que, o indicado é a ausência em $80 \%$ das amostras. Nesse ponto, os valores em NMP para coliformes totais observados foram os seguintes: 43 e 460, em 25/03 e 27/05, respectivamente (Figura 04). Analisando esses valores e observando a presente Resolução do CONAMA, as águas do Lajeado Erval Novo classificam-se como impróprias para o consumo humano, sem que ocorra um tratamento prévio.

Para coliformes termotolerantes os valores de NMP foram os seguintes: 150, e 240, em 25/03 e 27/05 de 2014, respectivamente, conforme a figura 04 . Nesse ponto de coleta, que fica à jusante da propriedade e num ponto avançado do Lajeado Erval Novo, observou-se um aumento gradativo na presença de coliformes da primeira para a última coleta de água. Isso pode ter sido influenciado 


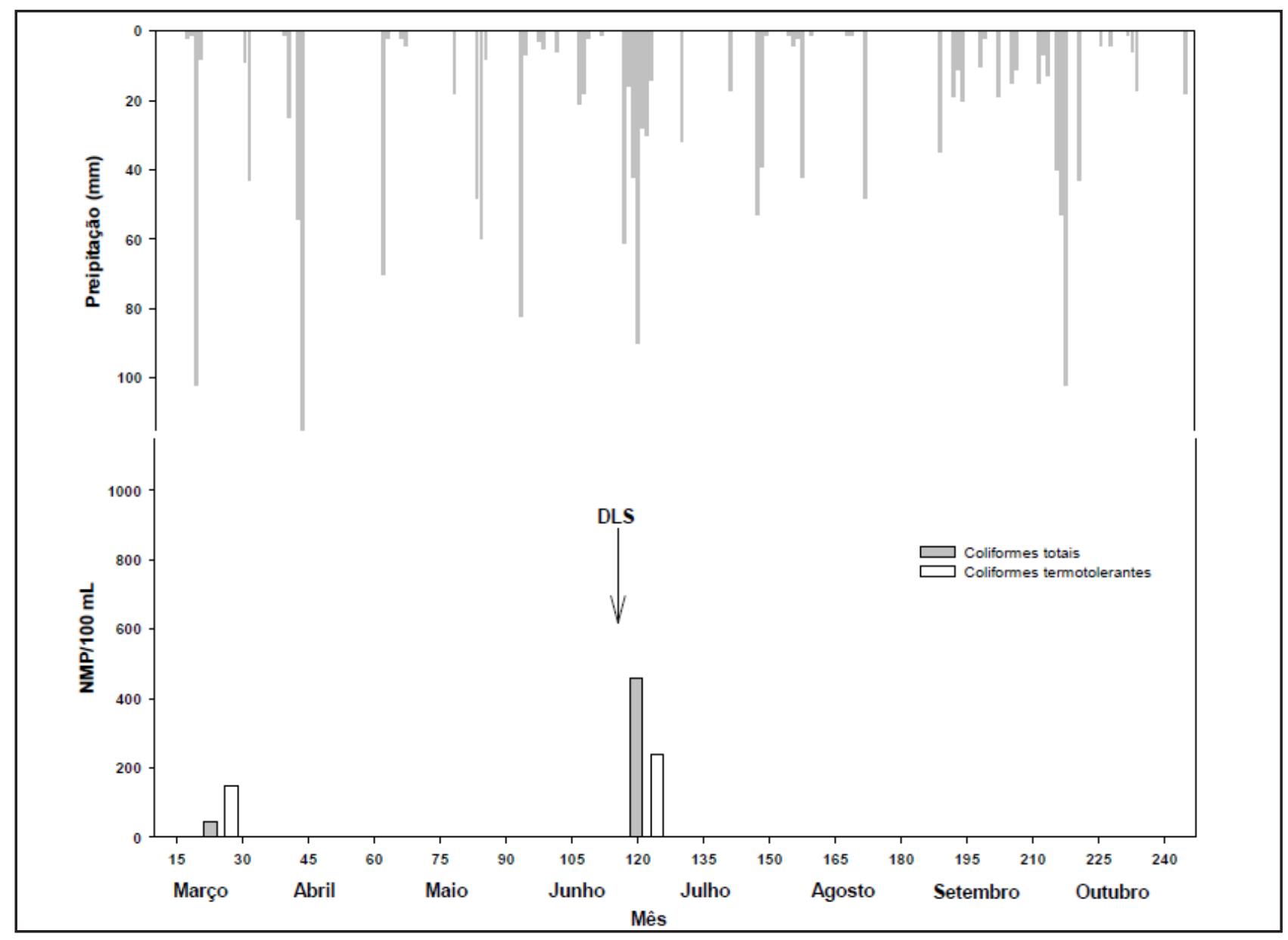

Figura 04 - Número Mais Provável (NMP) de coliformes totais e termotolerantes no ponto 6 de coleta de água e precipitação ocorrida entre os meses de março e outubro de 2014.

pela aplicação de DLS no solo na propriedade estudada aos 110 dias após o início das avaliações e também nas demais propriedades adjacentes ao Lajeado e aqui não mencionadas, que também recebem aplicações com DLS. Dessa forma, os microorganismos presentes nos DLS podem ter sido carregados com a água das chuvas para o Lajeado, contribuindo para os aumentos nos valores de coliformes observados nessas datas de coletas supracitadas. A lixiviação dos DLS da superfície do solo para a água pode não ocorrer inicialmente logo após a aplicação dos DLS, mas ocorrer de maneira lenta e gradual, propiciada pelas precipitações ocorridas entre as coletas. Em estudo avaliando a presença de coliformes no solo, Sá (2012) afirma, com base em seus resultados, que a liberação de bactérias a partir do DLS é gradual, e que a contaminação bacteriana proveniente da aplicação de DLS no solo pode se estender por um longo período de tempo.

Além dos coliformes, avaliou-se a presença de microorganismos aeróbios heterotróficos, que possuem relações com a presença bacteriológica na água, sendo que estas necessitam de carbono orgânico para sua existência (DOMINGUES et al., 2007). Para essa quantificação a medida padrão utilizada é Unidade Formadora de Colônias (UFC). Os valores de UFC no ponto 1 de coleta foram mais elevados que o ponto 6, ponto este com valores de UFC semelhantes ao ponto médio (PM), como pode-se observar na figura 05 .

Conforme Domingues et al. (2007), a importância da determinação da densidade de bactérias tem em vista que um aumento na população bacteriana pode comprometer a detecção de bactérias do grupo coliformes. Então, pode-se afirmar que no momento que as contagens de microorganismos aeróbios heterotróficos aumentaram, foi devido provavelmente porque os coliformes tiveram seu número reduzido nos dois pontos, em decorrência da disputa por carbono que ocorre entre os microorganismos. Quando se encontram microrganismos aeróbios heterotróficos na água, estes podem ser microorganismos indicadores de eutrofização, fenômeno este que pode ser natural ou artificial, sendo um processo lento e contínuo, resultante do aporte de nutrientes trazidos pelas chuvas e águas superficiais que desgastam e lavam a superfície terrestre (MACEDO e SIPAÚBA-TAVARES, 2010), isso indica que o manejo dos efluentes, em estações de tratamento para efluentes humanos, como em bacias de estabilização para efluentes animais com grande disponibilidade de carbono orgânico, está ocorrendo de 


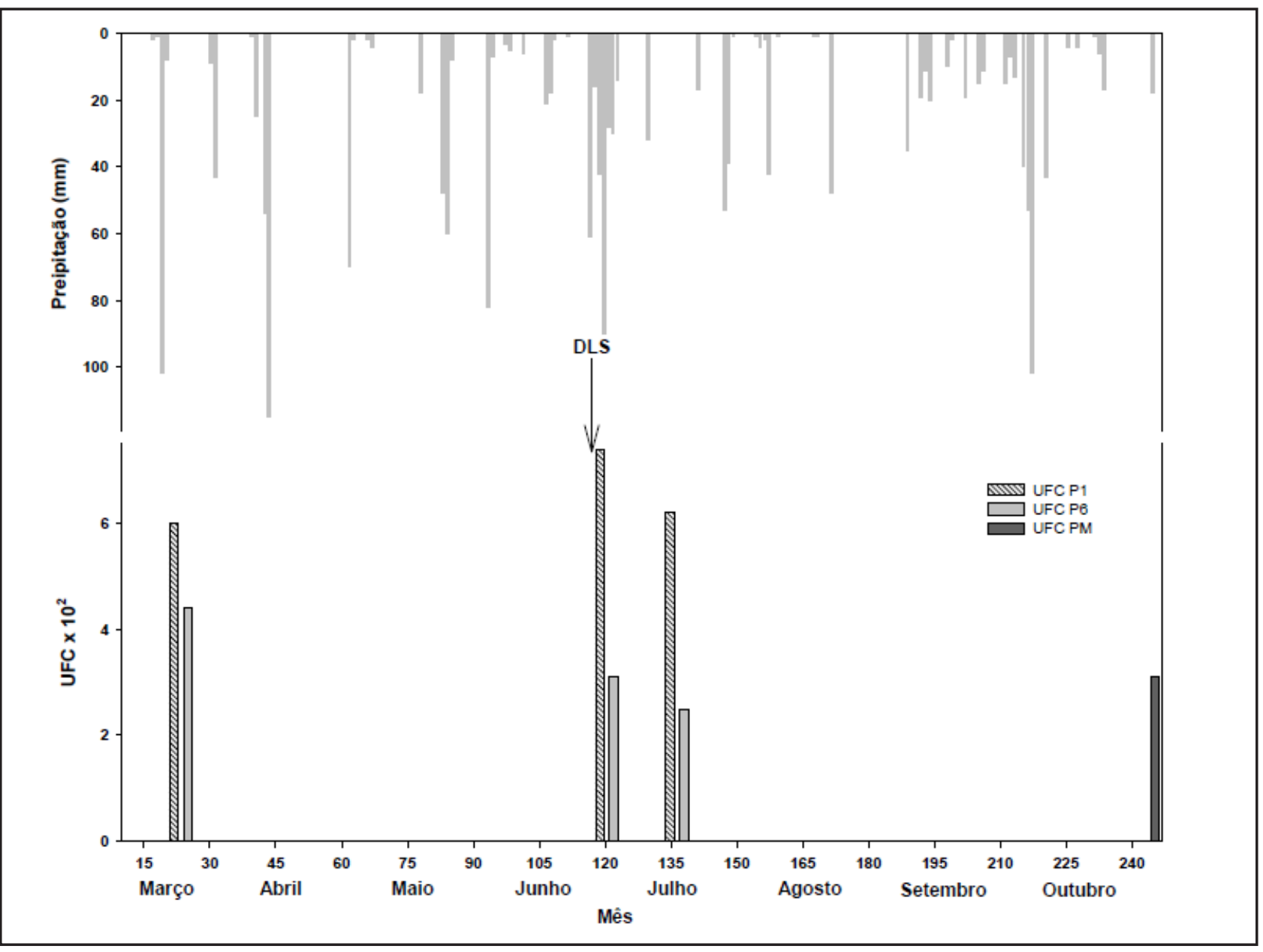

Figura 05 - Unidades Formadoras de Colônias (UFC) de micro-organismos aeróbios heterotróficos na água nos pontos 1, 6 e ponto médio - PM (média dos pontos 2, 3 e 5) de coleta e precipitação ocorrida entre os meses de março e outubro de 2014.

forma errônea, sendo despejados sem controle na água.

\section{Coliformes totais e termotolerantes no solo}

Para a confirmação da contaminação da água por coliformes totais e termotolerantes que podem estar relacionados com a prática de adubação orgânica com DLS, analisou-se a presença de coliformes totais e termotolerantes no solo, na profundidade média de $30 \mathrm{~cm}$, conforme a figura 06 .

Os resultados de NMP para coliformes totais foram de 2.300, 2.400, 6.800, 790 e 552 x 102, em 25/03, 26/05, 23/07, 02/09 e 25/10 de 2014, respectivamente. Nesse mesmo período, os resultados de NMP para coliformes termotolerantes foram de 23, 130, 1,8, 2 e $222 \times 102$ nas mesmas datas de coletas.

Observa-se que no período compreendido entre março e julho os valores de coliformes totais, mesmo após a aplicação de DLS no solo em área agricultável, foram constantes. Após esse período, ocorreu uma redução nos valores, corroborando com os resultados encontrados por Cargnin (2006) em um estudo semelhante. Essa redução pode ser explicada pelas flutuações de temperatura, umidade e exposição à radiação solar (GESSEL et al., 2004 apud CARGNIN, 2006), que causam variações na população de micro-organismos no solo. Além disso, a disponibilidade de carbono e nutrientes no solo pode ter ativado a microbiota nativa do solo, que disputa os nutrientes com os coliformes, contribuindo assim, para a redução desses últimos. As precipitações também pode ter auxiliado para a redução das populações de coliformes (CARGNIN, 2006).

Dessa forma, o presente estudo que buscou desde o início verificar a presença de microorganismos nas águas do Lajeado Erval Novo e no solo de uma área em uma propriedade adjacente ao seu curso, conseguiu demonstrar que essas águas e também o solo apresentam contaminação pelo grupo dos coliformes e, que esses podem ser influenciados pelas chuvas, aplicações de DLS e outros fatores ambientais. Assim, medidas mitigatórias deverão ser tomadas dentro do escopo ambiental e agrícola, no intuito de se ter uma melhor qualidade das águas, que também são utilizadas para o consumo humano e, do solo, que é utilizado para a 


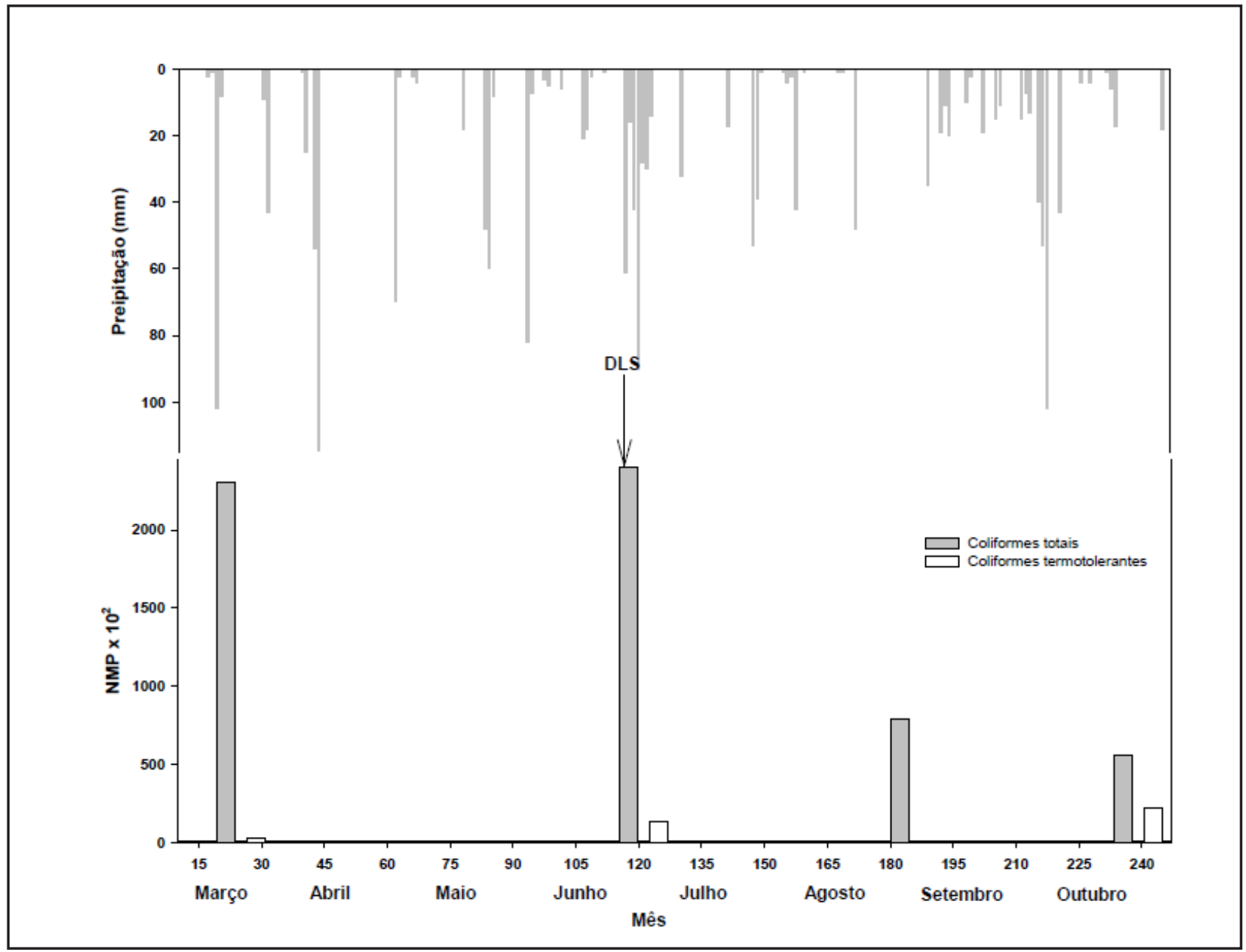

Figura 06 - Número Mais Provável (NMP) de coliformes totais e termotolerantes no solo no ponto 4 de coleta e precipitação ocorrida entre os meses de março e outubro de 2014.

produção de alimentos.

\section{Conclusões}

As águas do Lajeado Erval Novo apresentaram contaminação por coliformes e por bactérias aeróbias heterotróficas, indicando presença de matéria orgânica de origem fecal na água. As águas do Lajeado não se classificam como potável conforme a Resolução $\mathrm{n}^{\circ}$ 357/2005 do CONAMA. O solo apresentou contaminação por coliformes, indicando que a utilização de DLS em áreas agricultáveis não tem sido efetuada de maneira consciente.

\section{Agradecimentos}

Ao produtor que gentilmente cedeu sua propriedade para o desenvolvimento desse estudo. Aos professores do Curso de Especialização em Segurança Alimentar e Agroecologia e da Graduação em Gestão Ambiental, ambos da UERGS - Unidade Três Passos, que auxiliaram na construção do conhecimento. A UERGS pela oportunidade da realização do Curso e do presente estudo.

\section{Referências}

AMARAL, L. A. et al. Água de consumo humano como fator de risco à saúde em propriedades rurais. Rev. Saúde Pública, São Paulo, v. 37, n.4, 2013, p. 510-514.

BRASIL, Conselho Nacional do Meio Ambiente. Resolução n⿳o 357, de 17 de março de 2005. Dispõe sobre a classificação dos corpos de água e diretrizes ambientais para o seu enquadramento, bem como estabelece as condições e padrões de lançamento de efluentes, e dá outras providências.

CARGN/IN, R. H. O. et al. Persistência de coliformes em solo com aplicação de dejetos líquidos de suínos. In: 
Reunião Brasileira de Fertilidade do Solo e Nutrição de Plantas; Reunião Brasileira sobre Micorrizas; Simpósio Brasileiro de Microbiologia do Solo; Reunião Brasileira de Biologia do Solo, 2006, Dourados, Anais da Reunião Brasileira de Fertilidade do Solo...

CAVALCANTE, R. B. L. Ocorrência de Escherichia coli em fontes de água e pontos de consumo em uma comunidade rural. Rev. Ambiente \& Água, Taubaté, vol. 09, n.3, 2014, p. 550-558, jul./set..

DOMINGUES, V. O. et al. Contagem de bactérias heterotróficas na água para consumo humano: comparação entre duas metodologias. Rev. Saúde, vol. 33, n.1, 2007, p. 15-19.

DONEDA, A. A acidificação de dejetos líquidos de suínos afeta as emissões de amônia e gases de efeito estufa no processo de compostagem automatizada. (Thesis) Santa Maria: Programa de Pós-Graduação em Ciência do Solo, 2014, 99 p.

ECKHARDT, D. P. Potencial fertilizante de adubos orgânicos à base de esterco bovino e sua utilização na produção de mudas de alface. (Dissertation), Santa Maria: Programa de Pós-Graduação em Ciência do Solo, 2011, 99p.

JACOBSEN, C. S., BECH T. B. Soil survival of Salmonella and transfer to freshwater and fresh produce. Food Research International, n.45, p.557-566, 2012.

LEITE, A. M. O.; FRANCO, R. M. Coliformes totais e Escherichia coli em coxas de frango comercializadas no Rio de Janeiro. Rev. Brasileira de Ciências Veterinárias, v.13, n.2, 2006, p.80-83, maio/ago.

MACEDO, C. F.; SIPAÚBA-TAVARES, L. H. Eutrofização e qualidade da água na piscicultura: consequências e recomendações. Rev. Bol. Inst. Pesca, v.36, n. 2, 2010, p. 149-163.

MARQUES, M. G. Transformações do carbono e do nitrogênio no solo e produção de aveia com o uso de dejeto de suínos em plantio direto. (Dissertation) Santa Maria: Programa de Pós-Graduação em Ciência do Solo, 2005, 83 p.

MERTEN, G. H.; MINELLA, J. P. Qualidade da água em bacias hidrográficas rurais: um desafio atual para a sobrevivência futura. Rev. Agroecologia e Desenvolvimento Rural Sustentável, Porto Alegre, v.3, n.4, 2002, 33-38 p, out./dez.

MORALES, D. S. A. Resíduos sólidos de bovinos proveniente da estação de tratamento de efluentes de um frigorífico pelo processo de compostagem e vermicompostagem na produção de mudas de alface. (Dissertation) Santa Maria: Programa de Pós-Graduação em Ciência do Solo, 2011, 82 p.

PELCZAR JR, J. M.; CHAN, E. C. S.; KRIEG, N. R. Microbiologia: conceitos e aplicações. 2a ed., v.1, São Paulo: Pearson Education do Brasil, 1997.

REICHARDT, K.; TIMM, L. C. Solo, Planta e Atmosfera: conceitos, processos e aplicações. ${ }^{2}{ }^{a}$ Ed., Barueri: Manole, 2012, 500 p.

RESENDE, Á. V. de. Agricultura e qualidade da água: contaminação da água por nitrato. Documentos Embrapa Cerrados, Planaltina, DF: Embrapa Cerrados, 2002, 29 p.

RODRIGUES, H. J. B. et al. Variabilidade quantitativa de população microbiana associada às condições microclimáticas observadas em solo de floresta tropical úmida. Revista Brasileira de Meteorologia, v.26, n.4, 2011, p. 629-638.

SÁ, M. F. Dinâmica de populações de coliformes após a aplicação de dejetos suínos no solo e durante sua compostagem automatizada. Dissertação de Mestrado, Programa de Pós-Graduação em Ciência do Solo, Universidade Federal de Santa Maria - RS, 2012, 82 p.

SILVA, C. A. Uso de resíduos orgânicos na agricultura. In: SANTOS, G. de A. et. al. (Org.) Fundamento da matéria orgânica do solo: ecossistemas tropicais e subtropicais. 2ª ed. rev., Porto Alegre: Metrópole, 2008, p. 597-624.

STRECK, E. V. Solos do Rio Grande do Sul. 2 ed. Porto Alegre: EMATER/RS, 2008. 222 p.

UNC, A.; GOSS, M. J. Movement of faecal bacteria through the vadose zone. Water, Air, and Soil Pollution, 149, 327-337, 2004.

VASCONCELLOS, F. C. S.; IGANCI, J. R. V.; RIBEIRO, G. A. Qualidade microbiológica da água do Rio São Lourenço, São Lourenço do Sul, Rio Grande do Sul. Rev. Arq. Inst. Biol., São Paulo, v.73, n.2, p.177-181, abr./jun., 2006. 